\title{
The Influence of Quantum Learning Models on Scientific Attitude
}

\author{
Widdy Sukma Nugraha, Evin Dwi Evianty
}

Institut Pendidikan Indonesia

widisukma@institutpendidikan.ac.id

\section{Article History}

accepted 05/11/2020

approved 10/11/2020

published 01/02/2021

\begin{abstract}
The problem of this research was the scientific attitude that was consist of five dimensions, such as curiosity attitude, respect on the data, perseverance, cooperation with others, and sensitive on the environment of fifth grade. The objective of this research was to know the influence of quantum learning model on the students' scientific attitude of fifth grade in science subject. The method used quasi experimental with Nonequivalent Control Group design. The technique of collecting sample used saturation sampling. VA class as an experimental group that consist of 20 students. And VB class as control group that consist of 20 students. The instruments used questionnaire and observation. The technique of analysis in this research used t-test. It was aimed to find out the influence of quantum learning model on the students' scientific attitude. The result of this research showed that quantum learning model was significant influential on the students' scientific attitude of fifth grade in the material of panas dan perpindahannya. It took from the result of calculating data that showed sig. (2-tailed) $0.011<0.05$. Thus, it showed that Ha was accepted. Therefore, it could be concluded that using quantum learning model can influence the students' scientific attitude in science subject.
\end{abstract}

Keywords: scientific attitude, quantum learning model

\section{Abstrak}

Permasalahan dalam penelitian ini yaitu sikap ilmiah yang terdiri dari lima dimensi diantaranya sikap ingin tahu, sikap respek terhadap data, sikap ketekunan, sikap bekerjasama dengan orang lain dan sikap sensitive terhadap lingkungan sekitar pada kelas $\mathrm{V}$. Penelitian ini bertujuan untuk mengetahui pengaruh model pembelajaran quantum learning terhadap sikap ilmiah siswa kelas v pada mata pelajaran IPA di . Metode penelitian yang digunakan adalah Kuasi Eksperimen dengan desain Nonequivalent Control Group Design. Teknik pengambilan sampel dalam penelitian ini adalah Sampling Jenuh yaitu kelas VA sebagai kelompok eksperimen dengan jumlah siswa 20 dan kelas VB sebagai kelompok kontrol dengan jumlah siswa 20, sehingga total sampel dalam penelitian ini berjumlah 40 siswa. Instrumen yang digunakan adalah instrumen angket dan observasi.. Teknis analisis yang digunakan dalam penelitian ini adalah dengan menggunakan uji-t yakni untuk mengetahui apakah model pembelajaran quantum learning berpengaruh terhadap sikap ilmiah siswa atau tidak. Hasil penelitian menunjukkan model pembelajaran quantum learning berpengaruh signifikan terhadap sikap ilmiah siswa kelas $\mathrm{V}$ pada pokok pembahasan panas dan perpindahannya. Hal ini didasarkan pada hasil perhitungan data diperoleh nilai sig. (2-tailed) 0,011 $<0,05$ maka Ha diterima. Sehingga dapat disimpulkan bahwa penerapan model pembelajaran quantum learning dapat mempengaruhi sikap ilmiah siswa pada mata pelajaran IPA .

Kata kunci: model pembelajaran quantum learning, sikap ilmiah

Social, Humanities, and Education Studies (SHEs): Conference Series https://jurnal.uns.ac.id/shes

p-ISSN 2620-9284 e-ISSN 2620-9292 


\section{PENDAHULUAN}

Berdasarkan Undang-undang No.20 Tahun 2003 Tentang Sistem Pendidikan Nasional Pasal 3 yang menyatakan bahwa "Pendidikan nasional berfungsi mengembangkan kemampuan dan membentuk watak serta peradaban bangsa yang bermartabat dalam rangka mencerdaskan kehidupan bangsa, bertujuan untuk berkembangnya potensi peserta didik agar menjadi manusia yang beriman dan bertakwa kepada Tuhan Yang Maha Esa, berakhlak mulia, sehat, berilmu, cakap, kreatif, mandiri, dan menjadi warga negara yang demokratis serta bertanggung jawab". Fungsi dan tujuan pendidikan nasional tersebut secara umum jelas mengarah pada peningkatan kualitas bangsa. Kualitas bangsa ini tiada lain mencerminkan kualitas sumber daya manusia (SDM) suatu negara.

Sumber daya manusia sendiri mempunyai peranan yang sangat penting dalam pembangunan bangsa Indonesia khususnya dalam bidang pendidikan, sehingga untuk meningkatkannya dibutuhkan pendidikan yang baik. Tenaga pendidik dan kependidikan merupakan salah satu sumber daya manusia yang dapat menopang pendidikan dan merupakan salah satu aset negara yang harus terus menerus dikembangkan untuk mencetak insan-insan muda yang cerdas dan bermartabat. Guna menghasilkan sumber daya manusia yang berkualitas maka diperlukan proses pendidikan yang berkualitas pula. Kegiatan belajar mengajar di sekolah merupakan kegiatan yang sangat penting. "Berhasil tidaknya pencapaian tujuan pendidikan antara lain bergantung pada bagaimana proses belajar siswa di sekolah" (Rusman, 2016, hlm. 67). Sejalan dengan itu Syah (2010, hlm. 136) menyatakan bahwa "Pendidikan yang berkualitas ditunjukkan dari hasil-hasil belajar yang diperoleh siswa melalui proses belajar yang baik."

Pemahaman dan penguasaan konsep akan lebih mudah disampaikan guru jika sikap ilmiah sudah terbentuk pada diri siswa. Sikap ilmiah pada siswa identik dengan pembelajaran sains. "Sikap ilmiah memiliki keterkaitan dengan pembelajaran sains yang nantinya akan mempengaruhi perbuatan" (Sekarini, 2018, hlm. 2).

Melihat pendidikan saat ini, sikap ilmiah merupakan aspek yang sangat penting dalam pembelajaran. Namun pada kenyataanya, sikap ilmiah siswa di Indonesia masih rendah. Hal ini ditunjukkan oleh data Indonesia dalam peringkat Program for International Students Assesment (PISA) Mendikbud Muhadjir Effendy mengatakan, saat menghadiri pertemuan UNESCO di Paris november lalu, ada pertemuan dengan pimpinan pengelola PISA Indonesia di PISA pada tahun 2015 berada di urutan ke 72 dari 79 negara. Indonesia kalah jauh dari Vietnam yang berada di urutan ke 8 (Kemendikbud, 2016) Padahal aspek ilmiah sangat menentukan keberhasilan dalam proses belajar.

Sejalan dengan pendapat Prophen 1996 dalam Hunaepi (2016, hlm. 548) menyatakan bahwa ranah sikap ilmiah menentukan keberhasilan seseorang. Artinya ranah sikap ilmiah sangat menentukan keberhasilan seorang peserta didik untuk mencapai ketuntasan dalam proses pembelajaran. Aspek penting dalam pengetahuan dan penerapannya adalah aspek afektif atau sikap atau dalam pembelajaran sains sering dikenal dengan istilah sikap ilmiah. Dalam aspek sikap ilmiah, siswa dibelajarkan untuk membandingkan fakta yang ditemui terhadap dampak yang mungkin terjadi terhadap hasil belajar. Pophan (1995) mengatakan bahwa "ranah sikap ilmiah sangat menentukan keberhasilan seorang siswa untuk mencapai ketuntasan dalam proses pembelajaran" (Hunaepi, 2016, hlm. 548). Karakteristik ranah sikap ilmiah yang terpenting diantaranya sikap, minat, konsep diri, nilai dan moral.

Alternatif model pembelajaran yang dapat digunakan untuk mengatasi masalah tersebut ialah model pembelajaran quantum learning. Shoimin (2014, hlm 138) menyatakan bahwa "Model pembelajaran quantum adalah pengubahan belajar yang meriah dengan segala bernuansa ". Sedangkan menurut DePorter (2010, hlm. 34) quantum merupakan "Interaksi yang mengubah energi menjadi cahaya" Jika dikaitkan 
dengan proses pembelajaran pernyataan tersebut bermakna bahwa pengubahan bermacam-macam interaksi yang ada didalam dan disekitar momen atau lingkungan belajar disebut sebagai energi, dan interaksi-interaksi tersebut mencakup unsur- unsur untuk belajar efektif yang memengaruhi kesusksesan siswa. Oleh karena itu dengan menerapkan model pembelajaran quantum learning diharapkan dapat terwujud pembelajaran yang bermakna serta dapat memberikan pengaruh yang positif terhadap sikap ilmiah siswa pada mata pelajaran IPA. Berdasarkan latar belakang yang telah diuraikan, penulis tertarik untuk melakukan penelitian dengan judul "Pengaruh Model Pembelajaran Quantum Learning terhadap Sikap IImiah Siswa Kelas V Pada Mata Pelajaran IPA di SDN Pananjung 1".

\section{METODE}

Desain penelitian dalam penelitian ini adalah quasi exsperimental design . Bentuk desain eksperimen ini merupakan pengembangan dari true exsperimental design yang sulit dilaksanakan. Desain ini mempunyai kelompok kontrol, tetapi tidak berfungsi sepenuhnya untuk mengontrol variabel-variabel luar yang mempengaruhi pelaksanaan eksperimen. "Pada quasi exsperimental design ini terbagi dua bentuk desain quasi exsperimental design, yaitu Time Series Design dan Nonequivalent Control Group Design" (Sugiyono, 2013, hlm. 77). Bentuk desain quasi experimen yang digunakan dalam penelitian ini adalah Nonequivalent Control Design. Desain ini hampir sama dengan pretest-posttest control group design, hanya pada desain ini kelompok eksperimen dan kelompok kontrol tidak dipilih secara random (Sugiyono, 2013, hlm.79). Sampel dalam penelitian ini adalah kelas V A (sebagai kelompok eksperimen) sebanyak 20 orang dan V B (sebegai kelompol kontrol) sebanyak 20 orang. Pengumpulan data, peneliti menggunakan angket untuk melihat respon siswa terhadap pembelajaran dan juga observasi untuk melihat sikap ilmiah siswa.

\section{HASIL DAN PEMBAHASAN}

Secara umum penelitian ini bertujuan untuk mengetahui adakah pengaruh penerapan model pembelajaran quantum learning terhadap sikap ilmiah siswa di kelas V SDN Pananjung 1 pada pokok bahasan panas dan perpindahannya. Berdasarkan hasil analisis data yang telah dilakukan menunjukkan bahwa adanya perbedaan ratarata antara kelas eksperimen dengan kelas kontrol yang dilihat dari hasil tes kemampuan awal (pre-test) dan kemampuan akhir (post-test). Untuk mengetahui perbedaan dari kelas eksperimen dan kontrol dapat dilihat dari nilai rata-rata kemampuan tes awal dan tes akhir dari kedua kelas tersebut. Hal ini bisa ditunjukan dari hasil pre-test kelas eksperimen $\mathrm{x}=30,392$ dan kelas kontrol $\mathrm{x}=31,129$ dari ratarata nilai pre-test kelas eksperimen dan kelas kontrol dapat disimpulkan bahwa kedua kelompok tersebut memiliki kemampuan awal yang sama atau tidak berbeda signifikan. Hasil pre-test dan post- test selengkapnya dapat dilihat pada tabel 1. 
Tabel 1. Hasil Pre- test dan post-tes Kelas Eksperimen dan Kelas Kontrol

\begin{tabular}{|c|c|c|c|}
\hline \multirow{3}{*}{ No } & \multicolumn{3}{|c|}{ Kelas Eksperimen } \\
\cline { 2 - 4 } & Inisial & Pre-test & Post-test \\
\hline $\mathbf{( 1 )}$ & $\mathbf{( 2 )}$ & $\mathbf{( 3 )}$ & $\mathbf{( 4 )}$ \\
\hline 1 & S-1 & 29,607 & 33,116 \\
\hline 2 & S-2 & 27,306 & 30,742 \\
\hline 3 & S-3 & 31,627 & 32,204 \\
\hline 4 & S-4 & 28,381 & 34,097 \\
\hline 5 & S-5 & 29,283 & 33,860 \\
\hline 6 & S-6 & 27,589 & 32,442 \\
\hline 7 & S-7 & 30,439 & 33,914 \\
\hline 8 & S-8 & 27,707 & 31,180 \\
\hline 9 & S-9 & 28,183 & 32,682 \\
\hline 10 & S-10 & 29,220 & 29,618 \\
\hline 11 & S-11 & 31,445 & 39,619 \\
\hline 12 & S-12 & 28,498 & 39,080 \\
\hline 13 & S-13 & 31,390 & 18,816 \\
\hline 14 & S-14 & 31,070 & 29,145 \\
\hline 15 & S-15 & 32,867 & 25,215 \\
\hline 16 & S-16 & 27,495 & 41,275 \\
\hline 17 & S-17 & 34,868 & 22,571 \\
\hline 18 & S-18 & 32,575 & 41,275 \\
\hline 19 & S-19 & 35,093 & 28,275 \\
\hline 20 & S- 20 & 33,193 & 15,448 \\
\hline & JUMLAH & 607,835 & 624,576 \\
\hline RATA-RATA & 30,392 & 31,229 \\
\hline
\end{tabular}

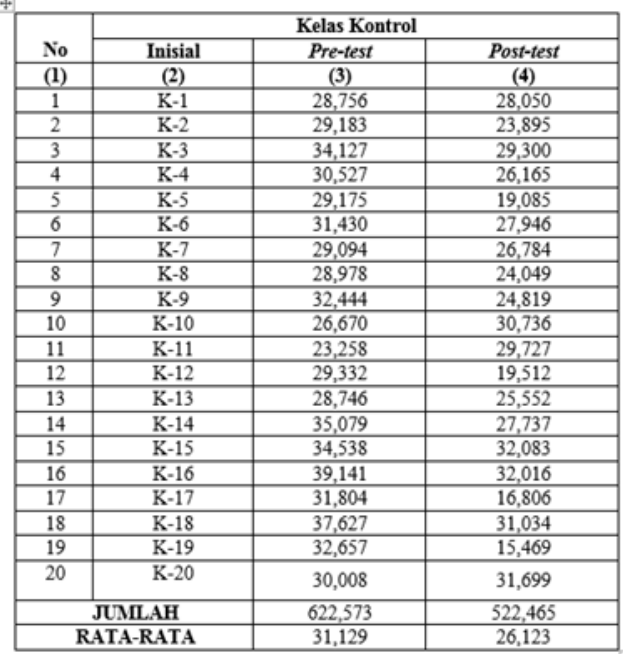

Model quantum learning adalah model pembelajaran yang menyenangkan dilakukan dengan memadukan pembelajaran dan keterampilan serta menghasilkan peserta didik yang aktif dalam belajar sehingga dapat meningkatkan sikap ilmiah siswa dalam pembelajaran IPA. Model pembelajaran quantum learning adalah "Pengubah belajar yang meriah, dengan segala bernuansa" (Shoimin, 2014, hlm. 138). De Porter (2015, hlm. 15) menyatakan bahwa quantum learning sebagai "interaksi -interaksi yang mengubah energi menjadi cahaya". Semua kehidupan adalah energi. Quantum learning menciptakan suasana pembelajaran menjadi lebih aktif dan tidak monoton, hal ini juga diperkuat oleh Sunandar 2012 dalam (Suryanti,Yunianta, 2018, hlm. 152) menyatakan bahwa kelebihan dari quantum learning yaitu; selalu berpusat pada apa yang masuk akal bagi siswa, menumbuhkan dan menimbulkan antusiasme siswa, adanya kerjasama, menawarkan ide dan proses cemerlang dalam bentuk yang enak dipahami siswa, menciptakan tingkah laku dan sikap kepercayaan dalam diri sendiri, belajar terasa menyenangkan.

Berdasarkan asumsi tersebut sikap ilmiah dapat meningkat karena adanya perlakuan menggunakan model quantum learning. Seperti halnya sikap igin tahu, Huda (2018) menyatakan bahwa langkah quantum learning menjadikan anak lebih kreatif. Siswa kreatif adalah siswa yang ingin tahu, suka mencoba dan senang bermain. Sama hal nya untuk melihat peningkatan sikap respek terhadap data, DePorter \& Hernacki (2011) menyatakan bahwa quantum learning mempunyai kelebihan yaitu bersifat integritas dimana dalam pembelajaran bersikaplah apa adanya, tulus dan jujur. Sementara itu untuk melihat peningkatan sikap ketekunan, Sunandar (2012) mengemukakan bahwa kelebihan quantum learning selalu berpusat pada apa yang masuk akal bagi siswa. Sedangkan menurut DePorter \& Hernacki (2011) keunggulan quantum learning adalah mengakui kegagalan dan dapat membawa kesuksesan artinya dalam pembelajaran siswa harus mengerti dan mengakui bahwa kesalahan atau kegagalan dapat memberikan informasi yang diperlukan untuk belajar lebih lanjut sehingga siswa dapat berhasil. Kemudian untuk melihat sikap bekerjasama dengan orang lain, Dan untuk melihat sikap sensitive terhadap lingkungan sekitar, menurut Huda (2018) langkah quantum learning yang tepat yaitu dengan penataan lingkungan belajar. Dalam proses belajar mengajar, diperlukan penataan lingkungan yang dapat membuat siswa merasa aman dan nyaman.

Dari pengujian hipotesis dengan statistik parametrik yaitu menggunakan uji $t$ dua sampel bebas atau independent t-test dari kedua kelas menunjukan bahwa terdapat pengaruh terhadap sikap ilmiah siswa yang signifikan antara kelas yang 
menggunakan model pembelajaran quantum learning dengan kelas yang menggunakan model pembelajaran konvensional. Hasil uji hipotesis menunjukkan bahwa penerapan model pembelajaran quantum learning berpengaruh signifikan terhadap sikap ilmiah siswa di kelas V SDN Pananjung 1 pada pokok pembelajaran panas dan perpindahannya. Hal ini didasarkan pada hasil dari perhitungan SPSS diperoleh nilai sig. (2- tailed) 0,011 < 0,05 maka Ha diterima. Berdasarkan kriteria pengujiannya maka dapat diambil kesimpulan bahwa terdapat pengaruh yang signifikan model quantum learning terhadap sikap ilmiah siswa kelas $V$ SDN Pananjung 1.

Meningkatnya sikap ilmiah siswa setelah diterapkannya model quantum learning disebabkan karena dalam pembelajaran quantum learning, guru mengajak siswa untuk lebih menumbuhkan minat belajarnya dalam tahap tumbuhkan. Sebelum belajar siswa akan disuguhkan instrumen berupa musik yang dapat membangun suasana kelas menjadi lebih nyaman. Jika dibandingkan dengan pembelajaran konvensional, pembelajaran dengan cara quantum learning dapat memberikan pengalaman baru dan siswa pun leluasa bergerak aktif sehingga proses pembelajaran tidak membuat bosan karena sebelumnya siswa hanya mendengarakan dan duduk dibangku masing-masing saja. Kemudian dalam pembelajaran quantum learning guu selalu menuntun siswa untuk mengulangi terus-menerus apa yang telah mereka pelajari sampai mereka tahu apa yang sedang mereka pelajari. Selain itu menurut (De Porter \& Hernacki, 2011, hlm 16) bahwa quantum learning memiliki keunggulan bahwa pembelajaran quantum mengutamakan keberagaman dan kebebasan bukan keseragaman dan ketertiban.

Keberhasilan ini tidak terlepas dari proses pembelajaran quantum learning yang meliputi beberapa tahapan yang dikenal dengan sebutan TANDUR. Enam langkah pembelajaran tersebut meliputi "Tumbuhkan, alami, namai, demonstrasikan, ulangi, dan rayakan" (De Porter, 2010, hlm. 39).

Dengan demikian berdasarkan paparan diatas dapat disimpulkan bahwa berdasarkan uji hipotesis yang telah dilakukan, hasil dari perhitungan SPSS diperoleh nilai sig. (2- tailed) 0,011<0,05 maka Ha diterima. Berdasarkan kriteria pengujiannya maka dapat diambil kesimpulan bahwa terdapat pengaruh yang signifikan model quantum learning terhadap sikap ilmiah siswa pada pokok pembahasan energi dan perpindahannya.

Kemudian untuk data observasi telah dipaparkan diatas bahwa dari ketiga tahapan memiliki perbedaan tetapi secara keseluruhan ketercapain pembelajaran nya tercapai maksimal yaitu untuk pertemuan pertama presentase keterlaksanaan tahapan pembelajarannya yaitu $80,65 \%$ dimana interpretasi nya berada di angka (75 $\leq$ $\mathrm{KP}<100)$ atau tahapan hampir seluruh kegiatan terpenuhi. Kemudian untuk pertemuan kedua presentaseketerlaksanaan tahapan pembelajarannya yaitu masih sama dengan tahapan pertama berjumlah $80,65 \%$ dimana interpretasi nya berada di angka $(75 \leq \mathrm{KP}<100)$ atau tahapan hampir seluruh kegiatan terpenuhi. Sedangkan untuk tahapan ketiga atau tahapan terakhir presentase keterlaksanaan tahapan pembelajarannya yaitu $100 \%$ dimana interpretasi nya berada di angka $(\mathrm{KP}=100)$ atau tahapan seluruh kegiatan terpenuhi.

\section{SIMPULAN}

Berdasarkan hasil penelitian yang peneliti lakukan serta perhitungan dan analisis data dari hasil pengukuran, maka pada bagian ini peneliti dapat mengemukakan kesimpulan bahwa berdasarkan uji hipotesis yang telah dilakukan, hasil dari perhitungan SPSS diperoleh nilai sig. (2-tailed) 0,011<0,05 yang menyatakan bahwa Ha diterima, yang berarti bahwa model quantum learning berpengaruh terhadap sikap ilmiah siswa. Berdasarkan kriteria pengujiannya maka 
dapat diambil kesimpulan bahwa terdapat pengaruh yang signifikan model quantum learning terhadap sikap ilmiah siswa pada pokok pembahasan panas dan perpindahannya.

\section{DAFTAR PUSTAKA}

De Porter, Bobbi \& Hernacki, Mike. (2015). Quantum Learning Membiasakan Belajar dan Menyenangkan. Bandung: PT Mizan Pustaka

Hunaepi. (2016). Kajian Literatur tentang Pentingnya Sikap Ilmiah. Prosiding Seminar Nasional Pusat Kajian Pendidikan Sains dan Matematika "Assessment of Higher Order Thinking Skills". Mataram

Huda. (2018). Model-model Pengajaran dan Pembelajaran. Yogyakarta: Pustaka Pelajar

Rusman. (2016). Model-Model Pembelajaran. Depok: PT RajaGrafindo Persada

Sekarini, Putri.R. (2018). Pengaruh Model Pembelajaran Quantum Learning Terhadap Hasil Belajar dan Sikap IImiah Siswa Kelas XI. Skripsi pada Universitas Islam Negeri Syarif Hidayatullah (UIN). Jakarta. Tidak dipublikasikan

Suryati, Wiwin. Yunianta, H.N.T, (2018). Penerapan Model Pembelajaran Quantum Learning untuk Meningkatkan Hasil Belajar Matematika Materi Pecahan Pada Siswa Kelas VII SMP NEGERI 3 GETASAN. Fakultas Keguruan dan IImu Pendidikan Universitas Kristen Satya Wacana. Volume 2. No.1. Hal.152

Shoimin, A. (2014). 68 Model Pembelajaran Inovatif dalam Kurikulum 2018. Yogyakarta: Ar-ruzz Media

Sugiyono. (2015). Metode Penelitian Pendidikan Pendekatan Kuantitatif, Kualitatif, dan R\&D. Bandung: Alfabeta

Sugiyono. (2016). Metode Penelitian Administrasi. Bandung: Alfabeta

Syah, Muhibbin. (2010). Psikologi Pendidikan. Bandung: PT Remaja Rosdakarya 